\title{
ASSESSMENT OF THE INVESTMENT SECURITY LEVEL OF UKRAINE
}

\author{
LiudmylaAkimova ${ }^{1}$, Alla Lysachok ${ }^{2}$ \\ ${ }^{1}$ Doctor of Science (Public Administration), Professor, National University of Water and \\ Environmental Engineering, Rivne, Ukraine, l_akimova@ukr.net, ORCID: https://orcid.org/0000- \\ 0002-2747-2775 \\ ${ }^{2}$ postgraduate student, Lviv regional Institute for public administration of The National academy of \\ public administration, the President of Ukraine, Lviv, Ukraine, lysachok96@ukr.net, ORCID: \\ https://orcid.org/0000-0002-5716-487X
}

Abstract. The article analyzes the opinions of scientists on their interpretation of the concept of "investment security", and also provides its own definition of this concept. It is determined that today investment security is one of the key factors for ensuring economic security, and is an important component of the national one. It was revealed that the main problem in assessing investment security indicators is the diversity of approaches to their assessment. There are contradictions between individual citizens and the state, manifested in a kind of conflict of their interests, which creates social tension. This trend is explained by the fact that, on the one hand, the state is the guarantor of the economic security of citizens, and on the other, a source of threats. The sattier also analyzed the dynamics of investment security indicators from 2015-2019. Direct investments (equity) from EU countries to the Ukrainian economy for 2015-2019. (million US dollars). The main investor countries of FDI in Ukraine for 2015-2019 were identified. (million US dollars).

Keywords: security, investment security, investment appraisal, state, public administration, foreign direct investment .

JEL Classification: B40, C40, E22, F36, H00

Formulas: 2; fig.: 2; tabl.: 1; bibl.: 15.

Introduction. In modern market conditions of managing, as well as crisis processes, which are now present in the development of the Ukrainian economy. The state of economic security of the state is the determining factor in the socioeconomic development of enterprises, regions and the state as a whole; it is this type of security that is an important component of national security, which in turn ensures the growth rate of the country's national economy. One of the main factors contributing to ensuring economic security is the activation of the investment process, that is, the issue of attracting additional sources of financing for the Ukrainian economy, it is also necessary to promote the development of investment potential, which significantly leads to positive changes in the economic and social direction, which are important in conditions of socioeconomic instability Ukrainian economy. With the help of investments, it is possible to achieve sustainable economic growth of the economy, real structural changes in the national economy, which will lead to an increase in the quality of life of the population. Therefore, it is necessary to properly ensure the investment security of the state, since it is it that is an integral part of economic security, and has a direct impact on national security. It should be noted that, today, investment security is one of the key factors for ensuring economic security, and is an important component of the national. With the help of investments, it is possible to ensure stable socio-economic development of the 
Ukrainian economy. Consideration and analysis of the dynamics of attracting investments in the state economy allows us to determine its level of investment security, which in turn makes it possible to determine the state of the investment climate in Ukraine.

Literature review. Studies of the dependence and relationship of economic security with investment security are the subject of research by many scientists. It is proved that investments are a powerful source for the development of the state economy, and therefore are an important definition of the level of investment security of the country. Scientists A. Makukh and L. Rusnak (2015) "Investment security of Ukraine in the world economic security system", understand investment security as the process of ensuring such a state of the investment sphere, in which the economy is able to maintain and maintain a sufficient level of investment resources in the face of internal and external threats, which is necessary to ensure sustainable development and socioeconomic stability countries, the growth of competitiveness of its economy and the welfare of the population [1]. Researchers A. Meshcheryakov and L. Novikova (2013) "Investment security of the state", believe that investment security is the ratio between the size of a country's investment abroad and the investment received, which meets the needs of the domestic economy and maintains a positive balance of payments of the state [2, p. 24]. I. Gubenko (2012) "Monetary conditionality of the investment component of economic security of the national economy", under investment security refers to the state of the organization of investment processes, which ensures optimal satisfaction of the current needs of the economy in capital investments in terms of volume and structure, taking into account the efficient use and return of funds invested in achieving the optimal ratio between the size of foreign investment in the country and domestic abroad, maintaining a positive national balance of payments [3, p. 76]. Researcher N. Tatarenko (2000) "Teorii investytsii", in his works notes that investment security is the possibility of accumulating resources or capital investments [4, p. 24]. A. Baranovsky (2004) "Financial security in Ukraine (valuation methodology and collateral)", believes that investment security is the achievement of an investment level, which allows optimally satisfying the current investment needs of the national economy in terms of volume and structure, taking into account the efficient use and return of funds invested in the optimal ratio between the size of domestic and foreign investment, foreign investment in the country and domestic abroad, maintaining a positive national balance of payments [5, p. 366]. V. Kirilenko (2009) "Investment Process Management in the Context of Economic Security", sees investment security as the ability to maintain production accumulation and capital investment at a level that ensures the necessary rates of expanded reproduction, restructuring and technological re-equipment of the economy [6, p. 275] and other researchers. Investment security should be understood as the situation during which all the investment needs of the country's economy are 
satisfied, which provide the necessary pace of expanded reproduction and are protected from negative internal and external factors.

Despite the research available in the field of ensuring investment security, it remains a problem to determine and evaluate its level. Researchers determine the definitions of this concept, and also highlight the main threats and solutions, while not analyzing the main indicators of investment security, determines the relevance of this study.

Aims. The purpose of this study is to analyze the main indicators of ensuring investment security, namely, determining its integral indicator, which is an indicator of investment development and determines the level of ensuring investment security of the state. The main problem in assessing investment security indicators is the diversity of approaches to their assessment.

Methods. To study the main indicators of investment security, we used data from the State Statistics Service of Ukraine for various time periods. The following methods were used: a comparative analysis method to determine the dynamics of investment security indicators from 2015-2019; direct investments (equity) from EU countries in the Ukrainian economy for 2015-2019 (million US dollars); major investing countries for FDI in Ukraine for 2015-2019 (million US dollars); abstract logical method - for analytical generalization and formulation of conclusions.

Results. In the modern economic world, security is considered as a certain system of properties, which is reflected in all spheres of public life, and also has a significant impact on the development of man, society, and the state. Since economic security is an important component of the national, it reflects a causal relationship between the country's economic power, its military-economic potential and national security. The main subject of economic security is the state. Despite this, today there are contradictions between individual citizens and the state, which manifests itself in a kind of conflict of their interests and generates social tension. This trend is explained by the fact that, on the one hand, the state is the guarantor of the economic security of citizens, and on the other, a source of threats.

State regulation of the investment component of economic security is a combination of forms and methods that ensure: the unification of public and private interests; the formation in the economy of rational proportions between consumption, accumulation and investment; information forecasting, indicative regulation and measures of state influence on the investment market [7, p.5].

An important component of economic security is investment security, the latter is ensured subject to a certain investment standard, which allows you to: reproduce the intellectual potential and scientific and technological progress of the nation; create strategic reserves; to carry out expanded reproduction of fixed capital; conserve and restore natural resources; to overcome depressive phenomena in the regions of the country; maintain the competitiveness of the economy; keep environmental parameters at a safe level; guarantee steady GDP growth at the level of tasks of socio-economic development and international cooperation.

In addition, investment security has quantitative and qualitative criteria. The number of indicators (criteria) of the safe state of the economy should not exceed (be 
less) by the threshold values of indicators of the investment sphere. That is, the volume of investment should be sufficient to ensure economic growth of the state, and not just for self-reproduction of the economy, that is, it has a value exceeding $17 \%$ of GDP [8, p. 201].

The indicator of investment security is determined by international experience, which indicates that for stable economic growth of the country, the attraction of annual direct investments should be at the level of $6 \%$ of GDP. That is, to maintain investment security, attracting direct investment in the country's economy in relation to GDP should be at the level of:

$$
L_{i s 1}=\frac{F I}{G D P} \times 100 \geq 6 \%
$$

where LisI - level of investment security as a percentage; FI - the inflow of foreign investment in the country's economy for the period considered in monetary terms; GDP - gross domestic product for the period in question (in monetary terms).

The value of FI / GDP should be kept at 6\%, and the value of FDI / GDP (FDIvolume of foreign direct investment) should be kept at $25 \%$, which is the threshold value of investment security [9].

Also, the investment security indicator can be calculated as the ratio of the inflow of annual foreign direct investment to the number of residents of the country. Its threshold value should be at least $\$ 500$ per person (that is, to maintain investment security, the inflow of direct investment in the country's economy in relation to the population should be at the level of $\$ 500$ ).

$$
L_{i s 2}=\frac{F D I}{K_{p}} \times 100 \geq 500 \$
$$

where $K_{p}$ - is the population of the country.

If a country reaches the maximum investment security thresholds, then it is at the reform stage and additional investments should be attracted when the country's economy is stable, then the threshold values may be less. Table 1 presents the dynamics of indicators of investment security in Ukraine.

Having analyzed these calculations in table 1 , we can note that investment safety indicators are far from threshold values. In 2015-2019, the Lis1 indicator, over the past five years, this indicator is below the threshold value, that is, it indicates investment unattractiveness. The Lis 2 indicator has a steady upward trend during 2015-2019, but it should not be considered that the change in this indicator is positive, since this indicator improves due to a decrease in the population. To improve the performance of Lis1, Lis2, it is necessary to increase the investment attractiveness of the state, this can be done by minimizing risks and threats. 
Dynamics of investment security indicators from 2015-2019

\begin{tabular}{|c|c|c|c|c|c|c|}
\hline \multirow{2}{*}{ Indicators } & \multirow{2}{*}{$\begin{array}{l}\text { Threshold } \\
\text { values }\end{array}$} & \multicolumn{5}{|c|}{ Actual Values } \\
\hline & & 2015 & 2016 & 2017 & 2018 & 2019 \\
\hline $\begin{array}{l}\mathrm{L}_{\text {is } 1,} \text { FDI inflow to } \\
\text { GDP, } \%\end{array}$ & $\geq 6$ & 4,69 & 4,72 & 2,24 & 2,20 & 1,66 \\
\hline $\begin{array}{l}\text { Dynamics of } \\
\text { normalized values }\end{array}$ & - & \multicolumn{5}{|c|}{ Dangerous area } \\
\hline $\begin{array}{l}\text { Volume of } \\
\text { investments, \% of GDP }\end{array}$ & $20-25 \%$ & 41,64 & 41,97 & 36,65 & 24,79 & 23,46 \\
\hline $\begin{array}{l}\text { Dynamics of } \\
\text { normalized values }\end{array}$ & - & \multicolumn{3}{|c|}{ Dangerous area } & \multicolumn{2}{|c|}{ Safe area } \\
\hline $\begin{array}{l}\mathrm{L}_{\text {is2}}, \text { FDI inflows per } 1 \\
\text { person, USD }\end{array}$ & $\geq 500$ & 896,19 & 916,72 & 967,17 & 763,40 & 852,61 \\
\hline $\begin{array}{l}\text { Dynamics of } \\
\text { normalized values }\end{array}$ & - & \multicolumn{5}{|c|}{ Safe area } \\
\hline \multicolumn{7}{|c|}{ Initial Data } \\
\hline GDP, mln. UAH. & - & 1979458 & 2383182 & 2982920 & 3558706 & 3974564 \\
\hline $\begin{array}{l}\text { FDI inflow for } \\
\text { year, million dollars }\end{array}$ & - & 4321,8 & 4405,9 & 2511,1 & 2869,9 & 2531,1 \\
\hline $\begin{array}{l}\text { FDI, mln. Dollars (at } \\
\text { the end of the year) }\end{array}$ & - & 38356,8 & 39144 & 41104,6 & 32291,9 & 35809,6 \\
\hline $\begin{array}{l}\text { Population, million } \\
\text { people }\end{array}$ & - & 42,8 & 42,7 & 42,5 & 42,3 & 42,0 \\
\hline $\begin{array}{l}\text { Average annual } \\
\text { exchange rate }\end{array}$ & - & 21,49 & 25,55 & 26,6 & 27,32 & 26,04 \\
\hline
\end{tabular}

*Source: calculated by the authors based on $[10 ; 11 ; 12 ; 13 ; 14 ; 15]$

For the growth of the state economy, it is necessary to increase the share of investments in GDP to at least $25-30 \%$. Only under such conditions it is possible to create opportunities for the functioning of expanded reproduction. That is why it is worth considering direct investment (equity) from the EU to the Ukrainian economy during 2015-2019. (million US dollars) (Fig. 1).

From fig. 1. we see that the dynamics of FDI inflows (hereinafter referred to as foreign direct investment) from the EU countries to the Ukrainian economy tends to decrease. 


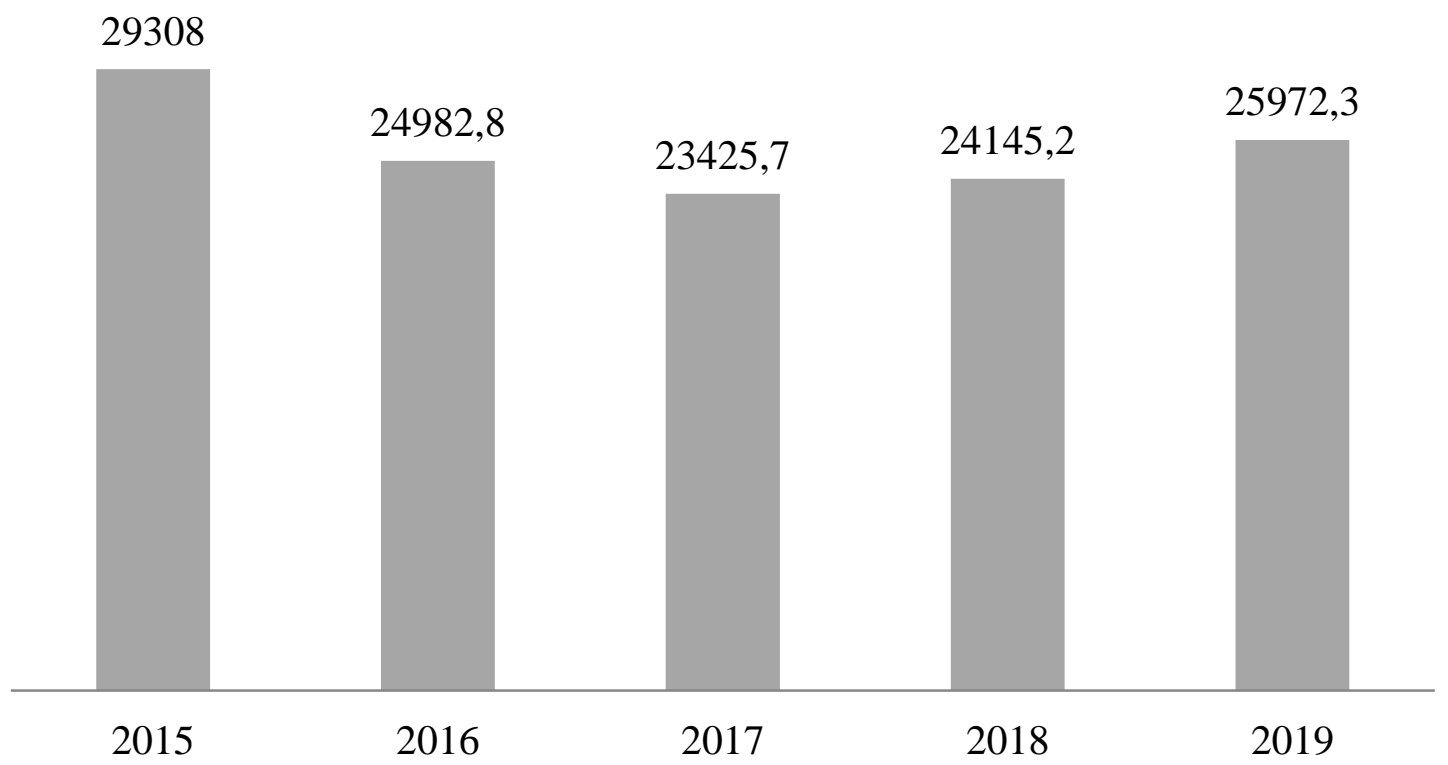

Fig. 1. Direct investments (equity) from the EU countries in the Ukrainian economy for 2015-2019 (million US dollars)

* Compiled by the authors based on the source [10; 13].

In 2019, they decreased by $\$ 3335.7$ million, in 2018 decreased by $\$ 5162.8$ million, in 2017 decreased by $\$ 5882.3$ million, and in 2016 by $4325, \$ 2$ million compared to 2015. It should identify the main countries investing in FDI in Ukraine for 2015-2019. (Fig. 2).

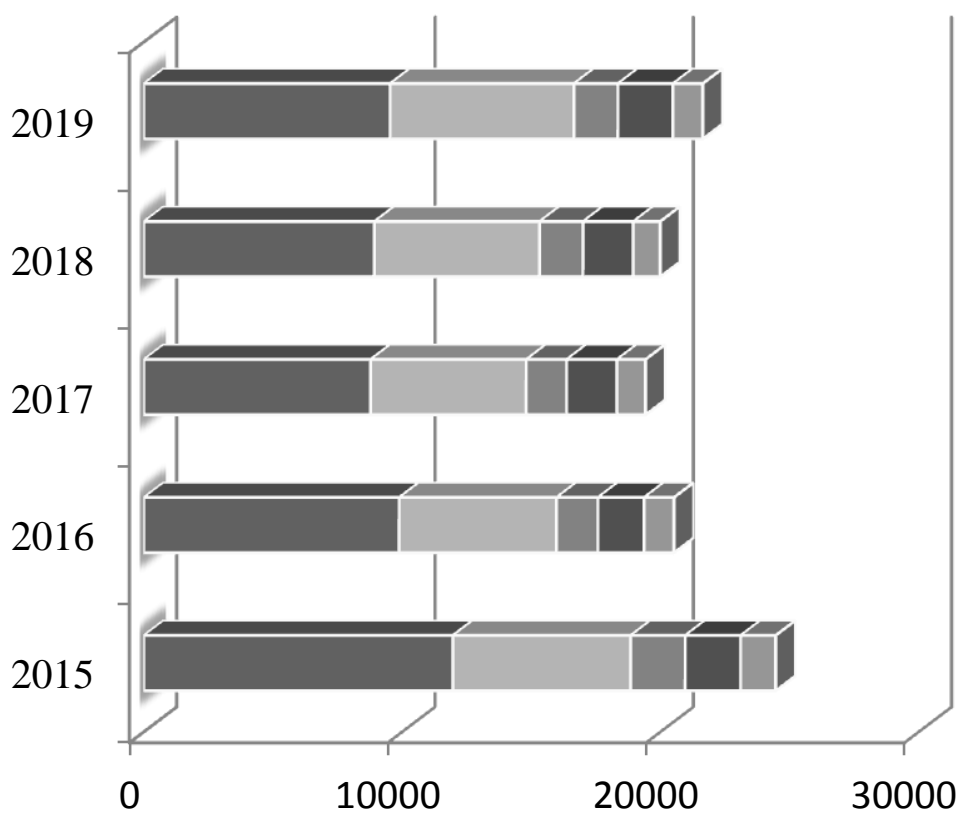

- Cyprus

Netherlands

Germany

- The United Kingdom of Great Britain and Northern Ireland

- Austria

Fig. 2. Key FDI investing countries in Ukraine for 2015-2019 (Mill. USD)* * Compiled by the authors based on the source [10; 13$]$. 
From fig. 2 we see that the main countries investing in Ukraine are Cyprus, the Netherlands, Germany, the United Kingdom of Great Britain and Northern Ireland, Austria. The main areas where foreigners invest in Ukraine are: industry 32.9\%; wholesale and retail trade - 16.2\%; financial and insurance activities $12.9 \%$; real estate operations $-12.9 \%$; professional, scientific and technical activities - 6.5\%. If we look at the IT sphere, then in the sphere of "Information and Telecommunications" for 2019 they invested 22 million dollars, and for all the time - 2.2 billion dollars or $6.5 \%$ of the total volume of FDI.

Discussion. The tendency in the state and among entrepreneurs to attract large volumes of foreign investment is not uniquely positive. Foreign investment, even if used effectively, should not make up a significant proportion of their total volume. In any state, the volume of foreign investment never exceeds the volume of Russian production. The experience of post-socialist European countries shows that foreign investment does not flow actively to places where there is not enough capital, but to places where investments are already actively being made, that is, they are "attracted" to domestic ones. External funds go to where economic reforms have already been implemented, primarily from their own sources. Foreign investment in the economy of a country depends on the economic and social conditions that have already developed.

To improve investment safety indicators, it is necessary to create a favorable investment environment, an investment climate that will be protected from external and internal threats. In addition, it is worth continuing the fight against corruption and encouraging domestic and foreign investors to invest in the Ukrainian economy, while it is necessary to develop all sectors and sectors of the economy, and not just those that now have a high level of investment investment. Summarizing the study, it can be stated that the conditions of investment security in Ukraine in the future remain very unfavorable for enhancing borrowing by enterprises of the real sector of the domestic economy. A lot of effort should be directed to restore the confidence of potential investors and ensure the efficient use of the financial resources received.

Conclusions.. Based on the results of the study, we can draw the following conclusions: today, in NAK there is no unambiguous definition of "investment security" in both domestic and foreign literature. Wherein. It should be noted that one of the main actors is the state, it has an impact on investment security, which in turn is an integral part of economic. The state is obliged to develop and implement a mechanism for ensuring investment security, that is, to send it interconnected in order to realize the economic interests of the Ukrainian economy. Since it is the investment component of economic security that determines the starting conditions for the development of investment policy, which in turn should be protected by investment, therefore, a constant and continuous analysis of the main components of the investment security of the state should be carried out. 
Thus, in our opinion, the provision of measures to strengthen investment Security can occur in the following areas:

- creation of forecasting mechanisms, identify and level existing threats by continuous monitoring;

- determination of legal, administrative, organizational means of counteracting existing threats to the investment security of the state and overcoming their consequences;

- creating a structure of the national investment market, has a margin of safety;

- the formation of transparent legal investment relations, an effective ownership structure and diversification of investment financing sources activities;

- the formation of a system of indicators for assessing the state investment security of the national economy for levels of investment potential, investment climate, innovation, investment activity.

Today, the level of investment security in Ukraine demonstrates negative trends, which can subsequently lead to the creation of an unfavorable investment image of Ukraine among European countries, which in turn can lead to a loss of opportunity to attract investment in the Ukrainian economy. A prompt response to the current state of investment security will lead to the timely identification of threats, and with the help of the state to determine ways to minimize them, which will make it impossible for a crisis in the Ukrainian economy to occur.

Acknowledgements. These studies will be relevant for scientists in the field of interests that are in the study of state investment security, as well as determining the level of its security. In addition to this research, they will help to develop a regulatory framework, practical measures and tools in the future, in turn, it will aim to develop a strategy for the development of the Ukrainian economy by ensuring the investment security of the state and providing it with an appropriate assessment.

Author contributions. The authors contributed equally.

Disclosure statement. The authors do not have any conflict of interest. References:

1. Makukh, A. and Rusnak, L. Investment security of Ukraine in the world economic security system. Retrieved from: http://intkonf.org/makuh-a-rusnak-l-investitsiyna-bezpeka.

2. Meshcheriakov, A. and Novikova, L. (2013), Investment security of the state. Visnyk Akademii mytnoi sluzhby Ukrainy, 2.pp. 23-29.

3. Hubenko, I. (2012). Monetary conditionality of the investment component of economic security of the national economy. Ekonomika i rehion,5, pp.75-80.

4. Tatarenko, N. and Poruchnyk, A. (2000), Teorii investytsii. Kyiv : KNEU.

5. Baranovskyi, O. (2004). Financial security in Ukraine (valuation methodology and collateral). Kyiv: Kiev. nat. trading econom Univ.

6. Nedashkivskyi, M. and Podhorna, K. (2012), Investment security of Ukraine in modern conditions. Zbirnyk naukovykh prats Natsionalnoho universytetu derzhavnoi podatkovoi sluzhby Ukrainy, I. pp. 274-280.

7. Kyrylenko, V.I. and Kyrylenko, L.M. (2009). Investment Process Management in the Context of Economic Security. Naukovyi chasopys, NPU imeni M.P.Drahomanova.Vyp 7. Seriia 18: p. 3-8.

8. Tokar, V.V., Tkalenko, S.I. (2019), Investment security in financial globalization. Vcheni zapysky Universytetu "Krok", 1(53). Retrieved from: http://snku.krok.edu.ua/index.php/vcheni-zapiskiuniversitetu-krok/article /view/165/186.

9. Pyrozhkov, S. I. (2003), Methodical recommendations for assessing the level of economic security in Ukraine. NIPMB, Kyiv, Ukraine. 
10. State Statistics Service of Ukraine. Retrieved from: http://www.ukrstat.gov.ua/

11.Ministry of Finance of Ukraine. Retrieved from: https://index.minfin.com.ua /ua/economy/fdi/.

12.National Bank of Ukraine. Retrieved from: https://bank.gov.ua/.

13.Kalyayev, Anatoliy., Efimov, Gennadiy., Motornyy, Volodymyr., Dzianyy Rostyslav., Akimova, Liudmyla (2019), Global Security Governance: Conceptual Approaches and Practical Imperatives. International Business Information Management Conference (33rd IBIMA). Granada, Spain 1011 April, 2019, pp. 4484-4495 [in Ukrainian].

14.Akimova L.M., Akimov O.O., Liakhovich O.O. (2017), State regulation of foreign economic activity. Scientific bulletin of Polissia. - № 4 (12). Part. 1. - pp. 98-103 [in Ukrainian].

15.Akimova, L. (2019), "State management as a subject of providing economic security of Ukraine: situation and content", Investytsiyi: praktyka ta dosvid, vol. 5, pp. 110-115. DOI: 10.32702/23066814.2019.5.110.

16.Panchenko, V., Mihus, I. ect. (2019) The Role of Investment Strategy in the Strategic Management System of Service Companies. Academy of Strategic Management Journal. EID: 2-s2.0-85080931094

Received: January 28, 2020 